\title{
Nye europeiske retningslinjer for forebygging av type 2-diabetes
}

\author{
Den europeiske arbeidsgruppen Development and Implementation of a European Guideline and Training \\ Standards for Diabetes Prevention (IMAGE) leverte sin plan for forebygging av type 2-diabetes på den sjette \\ verdenskonferansen for diabetesforebygging i Tyskland våren 2010. Forslagene i planen bør få stor betydning \\ i folkehelsearbeidet, siden type 2-diabetes er en raskt voksende epidemi.
}

Det er nylig publisert tre artikler fra IMAGE-gruppen: en oversiktsartikkel hvor effektiviteten av å kartlegge og forebygge type 2-diabetes gjennomgås (1), en hvor det beskrives et konkret verktøy for å drive forebyggingsarbeid (2) og en som inneholder beskrivelser av aktuelle opplæringsstrategier for dem som ønsker å lede forebyggingstiltak (3).

Verktøyet er et praktisk hefte som bygger på erfaringer fra ulike randomiserte og kontrollerte intervensjonsstudier (2). Forslagene er i overensstemmelse med Helsedirektoratets retningslinjer for diabetesforebygging (4), men er mer detaljerte på mange punkter. Målgruppen er alle som ønsker å starte et forebyggingstiltak i eller utenfor helseinstitusjoner. Vi håper dette redskapet blir oversatt til alle deltakerlandenes språk, også norsk.

\section{Hvem skal tilbys forebygging?}

For praktisk legearbeid er IMAGE-gruppens forslag til kriterier for forebygging nyttige. Særlig bør vi undersøke eldre, folk med type 2-diabetes i nær familie, fysisk inaktive og folk med kroppsmasseindeks $\geq 25 \mathrm{~kg} / \mathrm{m}^{2}$ $\left(23 \mathrm{~kg} / \mathrm{m}^{2}\right.$ for asiater) og folk med magemål $>94 \mathrm{~cm}$ (menn) eller $>80 \mathrm{~cm}$ (kvinner). Oral glukosetoleransetest er mye brukt. Testen kan forholdsvis lett gjøres i allmennpraksis ved å gi 75 g glukose i $2 \mathrm{dl}$ vann fastende om morgenen og måle blodsukkernivået fastende og etter to timer. Er totimersverdien i kapillært fullblod 7,8-11,0 mmol/1, foreligger det nedsatt glukosetoleranse.

Figur 1 (5) viser hvorfor denne tilstanden bør føre til forebyggingstiltak. De langerhanske øyer i pancreas har da lenge produsert økte mengder insulin på grunn av økt insulinresistens, og etter hvert oppstår det insulinmangel. Blodsukkernivået øker og etter hvert vil diabetes bli diagnostisert.

Figuren antyder to mulige tidspunkter for start av forebygging - enten når blodsukkernivået er noe forhøyet eller først når det er nedsatt glukosetoleranse. Er blodsukkernivået fastende 5,6-6,0 mmol/l i kapillært fullblod, bør man gjøre oral glukosetoleransetest $\mathrm{og}$ foreslå forebyggingstiltak. Effekten er bedre jo tidligere man starter.

IMAGE-gruppen foreslår følgende forebyggingsmål med individuell tilpasning (2):

- Økt fysisk aktivitet (rask gange, jogging, svømming, aerobic, ballspill, dans eller liknende) minimum 30 minutter per dag fem dager i uken

- Vektreduksjon på $5 \%$ ved overvekt eller fedme

- Redusert inntak av fett slik at fettet utgjør under $30 \%$ av energiinntaket

- Redusert inntak av mettet fett slik at det utgjør under $10 \%$ av energiinntaket

- Økt inntak av fiber, over $15 \mathrm{~g} / 1000 \mathrm{kcal}$

Av deltakerne i den finske Diabetes Prevention Study som ikke oppnådde noen av målene over, hadde $5 \%$ diabetes etter sju år, mens $4 \%$ av dem som oppnådde tre mål og ingen av dem som oppnådde alle fem mål hadde diabetes etter sju år (6).

\section{Befolkningsstrategi}

Befolkningsstrategier er å foretrekke fremfor individuelle høyrisikostrategier, fordi de aller fleste som får en sykdom, også type 2-diabetes, ikke hører til høyrisikoindividene. Jenum og medarbeidere har i et enestående prosjekt på Romsås i Oslo vist at forebyggingstiltak kan rettes mot en hel befolkning (7). Økt fysisk aktivitet og kostholdsomlegging er metodene. Her har vi lange tradisjoner i vårt land. Det nye ved type 2-diabetes er at vi kan opplyse om hvem som har økt risiko. Spørreskjemaet FINDRISC er velegnet i en befolkningsstrategi (4). Skår > 15 gir etter ti år $15 \%$ risiko for å ha diabetes og $45 \%$ risiko for å ha nedsatt glukosetoleranse (6). En forenklet utgave finnes på Helsedirektoratets nettsider (8).

\section{Forebyggingsgrupper}

Ifølge IMAGE-sammenslutningen er gruppebehandling er mest effektivt for å oppnå livsstilsforandring, slik vi har forsøkt blant pakistanske kvinner i Oslo (9). Forebyggingsgrupper kan organiseres på mange måter, organiseringen bør tillempes lokalt. 12-15 deltakere kan møtes i 3-8 sesjoner av to timers varighet. I vårt forsøk er viktigste tema blodsukkerreguleringens fysiologi. Teoriopplæringen kombineres med at deltakerne måler blodsukkernivå på seg selv før og etter måltid og fysisk aktivitet. $\mathrm{Da}$ ser de at teorien fungerer i praksis og kan selv trekke konklusjoner om sin livsførsel. Møtet bringer også gruppen sammen for turaktiveter.

Slike grupper må ha en leder. Det mest nyskapende fra IMAGE er et standardopplegg for utdanning av ledere, bestående av fem dagers undervisningsopplegg spredt over tre måneder med selvstudium mellom samlingene (3). Deltakerne kan ha bakgrunn fra helsetjenesten eller være interesserte lekfolk med en viss allmennkunnskap. Diabetesforbundet har lenge utdannet gruppeledere blant sine medlemmer (10), og kan forhåpentlig få anledning til å utvide dette tilbudet til flere enn medlemmene.
Figur 1 To stadier på veien til diagnose av type 2-diabetes, kroppens produksjon av insulin og glukose i blodet er under normal og forstyrret glukosetoleranse. Modifisert etter Matsuda og medarbeidere (5) 


\section{Kvalitetssikring og evaluering}

All forebyggingsaktivitet bør evalueres. IMAGE-gruppen foreslår at det gjøres ved å registrere antall planlagte intervensjonsbesøk som er gjennomført siste år, samt årlig endring i vekt, magemål, glukosenivå, kostholdskvalitet og fysisk aktivitet (3). Det er også satt opp kriterier for kvaliteten av screening og av befolkningsrettet forebygging.

\section{Konklusjon}

Forholdsvis mye gjøres i Norge når det gjelder tiltak for å forebygge type 2-diabetes, både på individ- og befolkningsnivå. Det er viktig å starte forebyggingstiltak i yngre aldersgrupper enn det vi har tradisjon for. Så vel Diabetesforbundet som Helsedirektoratet er aktive, men vi trenger en større offensiv. Det vil være en god start om vi i Norge følger forslagene fra IMAGE-gruppen.

\section{Bjørgulf Claussen}

bjorgulf.claussen@medisin.uio.no

Institutt for helse og samfunn

Universitetet i Oslo

Postboks 1130 Blindern

0318 Oslo

\section{Benedikte Bjørge}

Institutt for ernæringsvitenskap

Universitetet i Oslo

\section{Victoria Telle Hjellset}

Institutt for helse og samfunn

Universitetet i Oslo

Oppgitte interessekonflikter: Ingen

\section{Litteratur}

1. Paulweber B, Valensi P. Lindström J et al. A European evidence-based guideline for the prevention of type 2 diabetes. Horm Met Res 2010; 42 Isuppl 1): $\mathrm{S} 1-\mathrm{S} 36$

2. Lindström J, Neumann A, Sheppard KE et al. Take action to prevent diabetes. A toolkit for the prevention of type 2 diabetes in Europe.

3. Pajunen P, Landgraf R, Muylle F et al. Quality indicators for the prevention of type 2 diabetes in Europe - IMAGE. Horm Metab Res 2010. 42 (suppl 1): S56-S63.
4. Helsedirektoratet. Diabetes: forebygging, diagnostikk og behandling. Oslo: Helsedirektoratet, 2009

5. Matsuda M, DeFronzo RA. Insulin sensitivity indices obtained from oral glucose tolerance testing: comparison with the euglycemic insulin clamp. Diabetes Care 1999; 22: 1462-70.

6. Lindstrom J, Peltonen M, Eriksson JG et al. Finnish Diabetes Prevention Study (DPS) Group. Determinants for the effectiveness of lifestyle intervention in the Finnish Diabetes Prevention Study. Diabetes Care 2008; 31: 857-62.

7. Jenum AK, Lorentzen CA, Ommundsen Y. Targeting physical activity in a low socioeconomic status population: observations from the Norwegian 'Romsas in Motion' study. Br J Sports Med 2009; 43: $64-9$

8. Sjekk din diabetesrisiko. www.diabetesrisiko.no (21.9.2010).

9. Hjellset VT, Bjørge B, Eriksen HR et al. Risk factors for type 2 diabetes among female Pakistani immigrants: the InvaDiab-DEPLAN Study on Pakistani immigrant women living in Oslo, Norway. J Immigr Minor Health 2009; e-publisert 25.9.

10. Diabetesforbundet. www.diabetes.no/no/ Om_diabetes/Kurs og konferanser/ (21.9.2010).

Mottatt 10.8. 2010, første revisjon innsendt 21.9. 2010, godkjent 4.11. 2010. Medisinsk redaktør Are Brean. 